\title{
EFEKTY DZIAŁAŃ TERMOMODERNIZACYJNYCH W ASPEKCIE PLANOWANIA PROGRAMU REWITALIZACJI MIASTA
}

\author{
Anna Ostańska \\ Wydział Budownictwa i Architektury, Katedra Architektury, Urbanistyki \\ I Planowania Przestrzennego, Politechnika Lubelska \\ a.ostanska@pollub.pl
}

\begin{abstract}
Streszczenie. Zarządcy wielkich prefabrykowanych osiedli mieszkaniowych powstałych w latach 1970, ze względu rozmiar tych zasobów i ich daleki od doskonałości stan techniczny, są szczególnie zainteresowani poszukiwaniem rozwiązań pozwalających na zmniejszenie zużycia energii. W artykule opisano politykę publiczną wobec termomodernizacji w Polsce oraz pilotażowe badania ITB - próby określenia optymalnego zakresu działań termomodernizacyjnych w budynkach wielkopłytowych. Opisano również dotychczasowe działania termomodernizacyjne w skali jednego z lubelskich osiedli i określono kierunek dalszych działań służących oszczędności energii w budownictwie.
\end{abstract}

Słowa kluczowe: termomodernizacja, energooszczędność, rewitalizacja.

\section{WSTĘP}

Zarządcy wielkich prefabrykowanych osiedli mieszkaniowych powstałych w latach 1970, ze względu na sam rozmiar tych zasobów i ich daleki od doskonałości stan techniczny, są szczególnie zainteresowani poszukiwaniem rozwiązań pozwalających na zmniejszenie zużycia energii. Zakrojone na dużą skalę przedsięwzięcia termomodernizacyjne mogą stać się przyczynkiem do potraktowania problemu tych stosunkowo nowych zasobów w sposób całościowy i traktowanie ich jako punktu wyjścia przedsięwzięć rewitalizacyjnych.

\section{OBOWIĄZUJĄCA USTAWA}

Ustawa o wpieraniu termomodernizacji i remontów [Ustawa o wspieraniu... 2008] oraz związane z nią akty wykonawcze [RMI 2009 poz. 346, poz. 347] podają związane z zagadnieniem definicje, regulacje prawne, procedury postępowania i sposobu weryfikacji przy wykonywaniu audytu energetycznego lub remontowego.

Zgodnie $\mathrm{z}$ ustawą. przedsięwzięcie termomodernizacyjne - to ulepszenie zmniejszające zapotrzebowanie na energię na cele ogrzewcze i ciepłej wody, ulepszenie zmniejszające straty energii pierwotnej w lokalnych sieciach ciepłowniczych oraz zasilających je lokalnych źródłach (budynki podłączone do systemu spełniają wymagania zawarte w przepisach prawa budowlanego), wykonanie przyłącza technologicznego do scentralizowanego źródła ciepła w związku z likwidacją lokalnego źródła ciepła, całkowita lub częściowa zmiana źródła energii na źródła odnawialne lub kogeneracji;

przedsięwzięcie remontowe - to przedsięwzięcie związane z termomodernizacją, których przedmiotem jest: remont budynków wielorodzinnych, wymiana okien lub remont balkonów w budynkach wielorodzinnych, przebudowa budynku wielorodzinnego w wyniku której następuje ich ulepszenie, wyposażenie budynków wielorodzinnych w instalacje i urządzenia wymagane warunkami technicznymi.

Wymagany ustawą poziom oszczędności energii cieplnej w budynku uzyskanych w wyniku termomodernizacji to dla:

- systemu grzewczego - $10 \%$,

- modernizacji systemu grzewczego po 1984 r. - 15\%,

- pozostałych przypadków $-25 \%$. 
- wysokość premii termomodernizacyjnej może wynosić $20 \%$ wykorzystanej kwoty kredytu, jednak nie więcej niż 16 \% kosztów inwestycji i nie więcej niż dwukrotne (obliczone w audycie) roczne oszczędności kosztów energii.

- kredytu nie można otrzymać gdy zaciągnięto inny kredyt termo modernizacyjny lub uzyskano środki pochodzące z budżetu Unii Europejskiej.

- audyt energetyczny zawiera:

- dane identyfikacyjne budynku i inwestora,

- ocenę stanu technicznego budynku,

- opis możliwych wariantów realizacji przedsięwzięcia (tylko uzasadnione technicznie i ekonomicznie dla danego budynku),

- wskazanie wariantu optymalnego, w tym: określenie wielkości środków własnych inwestora, kwotę kredytu możliwego do zaciągnięcia przez inwestora i szczegółowy opis modernizacji systemu ogrzewania (jeżeli taka wystąpiła) po 1984 roku.

Premia remontowa może być przyznana wyłącznie dla budynków wielorodzinnych, których użytkowanie rozpoczęto przed 14 sierpnia 1961 roku (dokument lub pisemne oświadczenie). Ponadto co najmniej $10 \%$ z oszczędności energii należy przeznaczyć na potrzeby ogrzewania i przygotowania ciepłej wody, wskaźnik kosztu przedsięwzięcia od 0,05 do 0,70 (koszty robót w przeliczeniu na $1 \mathrm{~m}^{2}$ powierzchni użytkowej do ceny $1 \mathrm{~m}^{2}$ powierzchni użytkowej określanej dla celów premii gwarancyjnej), co najmniej 25\% oszczędności energii na potrzeby ogrzewania i przygotowania ciepłej wody jeżeli wskaźnik przekracza 0,30 i co najmniej $5 \%$ dla kolejnego przedsięwzięcia, chyba że wcześniej osiągnięto $25 \%$. Kredyt remontowy nie może być przeznaczony na:

- remont lokali w zakresie innym niż wymieniony w definicji przedsięwzięcia remontowego,

- prace prowadzące do zwiększenia powierzchni użytkowej,

- sfinansowanie prac na które pozyskano środki UE lub przyznana została premia termomodernizacyjna lub remontowa.

- wysokość premii remontowej może wynosić $20 \%$ wykorzystanej kwoty kredytu, jednak nie więcej niż 15\% kosztów przedsięwzięcia remontowego. Premia naliczana jest jedynie dla lokali mieszkalnych poprzez uwzględnienie udziału powierzchni użytkowej tych lokali w powierzchni użytkowej wszystkich lokali w budynku.

- audyt remontowy zawiera:

- dane identyfikacyjne budynku i inwestora,

- kalkulację wartości wskaźnika E (obliczeniowe zapotrzebowanie na energię końcową do ogrzewania w sezonie grzewczym),

- rzeczowy zakres robót umożliwiający uzyskanie wymaganego poziomu oszczędności energii,

- plan robót remontowych,

- wskazanie zakresu prac remontowych objętych wnioskiem,

- dokumenty określające szacowany koszt przedsięwzięcia (kosztorysy).

Premia kompensacyjna przysługuje osobie fizycznej, która w dniu 25 kwietnia 2005 roku była:

- właścicielem

- spadkobiercą właściciela

- po tym dniu została spadkobiercą właściciela budynku mieszkalnego, w którym był co najmniej jeden lokal kwaterunkowy.

Premię przyznaje się jeden raz dla danego budynku, łącznie z premią remontową, przeznaczona jest ona na częściową spłatę kredytu przeznaczonego na remont. Wysokość premii oblicza się wg wzoru zawartego w załączniku ustawy. Wniosek o premię kompensacyjną składa się wraz z wnioskiem o premię remontową, powinien on zawierać: dane identyfikacyjne budynku i inwestora, informacje o lokalach kwaterunkowych (powierzchnia użytkowa, 
ograniczenia w najmie), dokumenty potwierdzające sprawdzenie poprawności obliczenia premii kompensacyjnej wg wzoru z ustawy.

\section{WAŻNIEJSZE PRZEPISY I POLITYKA PUBLICZNA WOBEC TERMOMODERNIZACJI ${ }^{1}$}

W latach 70. na podstawie Uchwały nr 260 RM z grudnia 1981r. wprowadzono kredyty, które później umarzano, były to pierwsze próby likwidacji wad technologicznych. W ramach tych działań ocieplano, ale nie dostosowywano instalacji c.o. do zmniejszonego zużycia na moc cieplną, co polepszało jedynie warunki wewnętrzne użytkowanych pomieszczeń.

W 1991r. Instytut Techniki Budowlanej zaproponował koncepcję konwersji dotacji budżetowych na wspieranie przez państwo systemu kredytowania termomodernizacji budynków. Istotą koncepcji był zwrot kredytu z korzyści ekonomicznych spowodowanych termomodernizacją budynku. Do takich kredytów inwestor zobowiązany był do wykonania audytu energetycznego, w którym wskazano rozwiązanie optymalne, głównie z uwagi na opłacalność przedsięwzięcia i możliwość spłaty kredytu.

Ponadto ITB oceniło, że wpływ mostków cieplnych na izolacyjność cieplną przegród zewnętrznych $\mathrm{w}$ budynkach $\mathrm{z}$ wielkiej płyty jest $\mathrm{z}$ reguły większy niż wynika to z przyjmowanych dodatków do współczynnika przenikania ciepła w uproszczonej metody obliczania współczynnika przenikania ciepła wg załącznika krajowego NA do PN-EN ISO 6946:1999. [PN-EN ISO 6946:1999]

Ustawą o wpieraniu przedsięwzięć termomodernizacyjnych z grudnia 1998 r. [Dz.U. $\mathrm{Nr} 162$, poz. 1121, z późn. zm] zastąpiono dotacje budżetowe na ocieplanie ścian budynków spółdzielczych ogólnodostępnymi kredytami inwestycyjnymi na przedsięwzięcia podejmowane w celu zmniejszenia o co najmniej $10 \%$ zapotrzebowania na ciepło do ogrzewania budynków i przygotowania c.w.u.

Budynki wielkopłytowe charakteryzują się niską izolacyjnością cieplną i to od początku ich powstania. Sezonowe zapotrzebowanie na ciepło do ogrzewania budynków z wielkiej płyty jest zwykle od 50 do $100 \%$ wyższe, niż obowiązujące wymagania wyrażone za pomocą wskaźnika E (wskaźnik sezonowego zapotrzebowania ciepła do ogrzania $1 \mathrm{~m}^{3}$ ogrzewanej kubatury budynku).

Warunkiem otrzymania kredytu była opłacalność inwestycji, udokumentowana audytem energetycznym (określającym zakres i parametry kompleksowego przedsięwzięcia termomodernizacyjnego, tj. podwyższeniu izolacyjności cieplnej przegród budowlanych, modernizacji instalacji wewnętrznej c.o. i dostosowaniu jej do zmniejszonego zapotrzebowania na ciepło).

Likwidacja dotacji do ciepła stworzyła przesłanki do ustalenia grubości izolacji cieplnej w budynkach nowo wznoszonych. Może być ona różna w zależności od regionu kraju i mogłaby wynikać z rachunku opłacalności inwestycji wznoszonej na określonym terenie i przy założonej taryfie lokalnej.

Analiza pilotażowych badań ITB przeprowadzonych w latach 1999-2000 na warszawskich osiedlach z budynkami w systemach: szczecińskim, OWT-75, W-70 i Wk-70 wykazała, m.in. że optymalnym wariantem termomodernizacji dla budynków wielkopłytowych jest:

- docieplenie ścian zewnętrznych, stropodachu i stropu nad nieogrzewanymi piwnicami materiałem $\lambda=0,04 \mathrm{~W} /(\mathrm{mK})$ o grubości $14 \mathrm{~cm}$,

- ograniczenie średniej krotności wymiany powietrza w mieszkaniach i na klatkach schodowych do $0,5 \mathrm{~h}^{-1}$,

- wymiana okien w mieszkaniach na okna o współczynniku przenikania ciepła równym $1,3 \mathrm{~W} /\left(\mathrm{m}^{2} \mathrm{~K}\right)$ i wyposażenie w nawiewniki powietrza do pomieszczeń.

1 Niniejszy rozdział opracowano na podstawie [Pogorzelski 2000] oraz analizy własnej obowiązujących przepisów. 
Wybrany wariant (obliczony za pomocą programu MAIN) pozwolił osiągnąć wskaźnik zapotrzebowania na ciepło na poziomie $\mathrm{E}=21,5 \mathrm{kWh} /\left(\mathrm{m}^{3} \mathrm{rok}\right)$, gdzie przy współczynniku kształtu budynku $\mathrm{A} / \mathrm{V}=0,34$ wymagana wartość współczynnika $\mathrm{E}_{0}=30,73 \mathrm{kWh} /\left(\mathrm{m}^{3} \mathrm{rok}\right)$ [Dz.U. nr 15/99, poz. 140].

Z badań ITB (1999-2000) wynikła potrzeba opracowania w Polsce wiarygodnych danych wartości wskaźnikowych na temat pomiarów intensywności wentylacji mieszkań w budynkach wielorodzinnych dotyczących, np. krotności wymiany powietrza, będące podstawą do obliczeń strumienia powietrza wentylacyjnego (podane są jedynie uogólnione wartości) [8]. To niedoszacowanie poddawało $\mathrm{w}$ wątpliwość poziom diagnoz cieplnych i prawidłowość podejmowanych na ich podstawie decyzji dotyczących termomodernizacji budynków mieszkalnych. Brakowało też pełnego opracowania wytycznych do audytu energetycznego w zakresie rzeczywistej izolacyjności cieplnej przegród i wentylacji budynków mieszkalnych z wielkiej płyty, umożliwiających rzetelną analizę możliwości i opłacalności tych działań w skali ogólnopolskiej.

W listopadzie 2008 roku wraz z rozporządzeniem o zmianie warunków technicznych [Rozp. z dnia 6 listopada 2008] weszła w życie ustawa o wspieraniu przedsięwzięć termomodernizacyjnych i remontowych, którą opisano w p. 1.

W § 329 obowiązującego rozporządzenia usunięto wymaganie w zakresie limitowanego wskaźnika sezonowego zapotrzebowania energii na cele grzewcze (E) odnoszącego się do budynków mieszkalnych i zamieszkania zbiorowego w celu ustalenia dla wszystkich budynków jednolitego alternatywnego podejścia do spełnienia wymagań techniczno-budowlanych związanych z racjonalizacją użytkowania energii. Wprowadzono przepis dający możliwość wyboru drogi respektowania obowiązujących uregulowań standardu energetycznego poprzez: spełnienie wymagań cząstkowych $\mathrm{w}$ postaci dopuszczalnej izolacyjności cieplnej przegród oraz innych wymagań związanych z oszczędnością energii zawartych w rozporządzeniu lub spełnienie warunku, że wskaźnik EP projektowanego budynku określający roczne zapotrzebowanie na nieodnawialną energię pierwotną, obliczony wg zasad ustalonych w przepisach odrębnych dotyczących metodologii obliczania charakterystyki energetycznej nie przekroczy wskaźnika EP, obliczonego na podstawie prostych zależności określonych w ust. 3. Ponadto dla budynku, który jest poddawany przebudowie poprawiającej właściwości cieplne i charakterystykę energetyczną dopuszczono zwiększenie dopuszczalnej wartości EP maksymalnie o $15 \%$ w porównaniu z budynkiem nowym o takiej samej geometrii i sposobie użytkowania. Proponowane rozwiązanie miało na celu zachowanie na racjonalnym poziomie swobody projektowania przy uwzględnieniu rygorów wynikających z dyrektywy (2002/91/WE).

\section{DOTYCHCZASOWE DZIAŁANIA TERMOMODERNIZACYJNE NA PRZYKŁADZIE OSIEDLA IM. MONIUSZKI W LUBLINIE ${ }^{2}$}

Budynki zrealizowane w systemie wielkopłytowym OWT-67 stanowią sztywne skrzynie utworzone z prefabrykatów ścian wewnętrznych, zewnętrznych i stropowych, są bezpieczne pod względem nośności.

$\mathrm{Na}$ bezpieczeństwo analizowanego systemu wielkopłytowego ma wpływ prawidłowe wykonanie węzłów konstrukcyjnych. Trwałość takiego złącza jest mniejsza w przypadku niedokładnego spawania czy zabetonowania węzła i/lub zawilgocenia pomieszczeń. Przyczyną zawilgoceń są nieszczelności styków prefabrykatów i/lub przemarzanie ścian.

Z badań przeprowadzanych od 20. lat przez ITB wynika, że stan połączeń prefabrykatów w węzłach konstrukcyjnych jest dobry, mimo użycia wielu gatunków stali.

2 Niniejszy rozdział opracowano na podstawie [Ostańska 2009] . 
Poniżej poddano dokładniej analizie osiedle Moniuszki w Lublinie. Jest to osiedle ciekawe $^{3}$, ponieważ termomodernizacja następowała tu etapami po kolejnych doświadczeniach, opartych na podstawie zrealizowanych działań i analizie uzyskanych oszczędności energetycznych (Ryc. 11).

Badania osiedla przeprowadzono w latach 1996-2006 odtworzono w nich historię termomodernizacji budynków, zbadano ich stan techniczny w chwili obecnej ze szczególnym uwzględnieniem pozostawionych mostków termicznych i możliwych jeszcze do wprowadzenia oszczędności energetycznych oraz ogólnie oceniono stan instalacji w budynku.

Poniżej przedstawiono schematycznie problemy i podjęty zakres działań termomodernizacyjnych dla budynku wielkopłytowego (Ryc. 1) na analizowanym osiedlu.

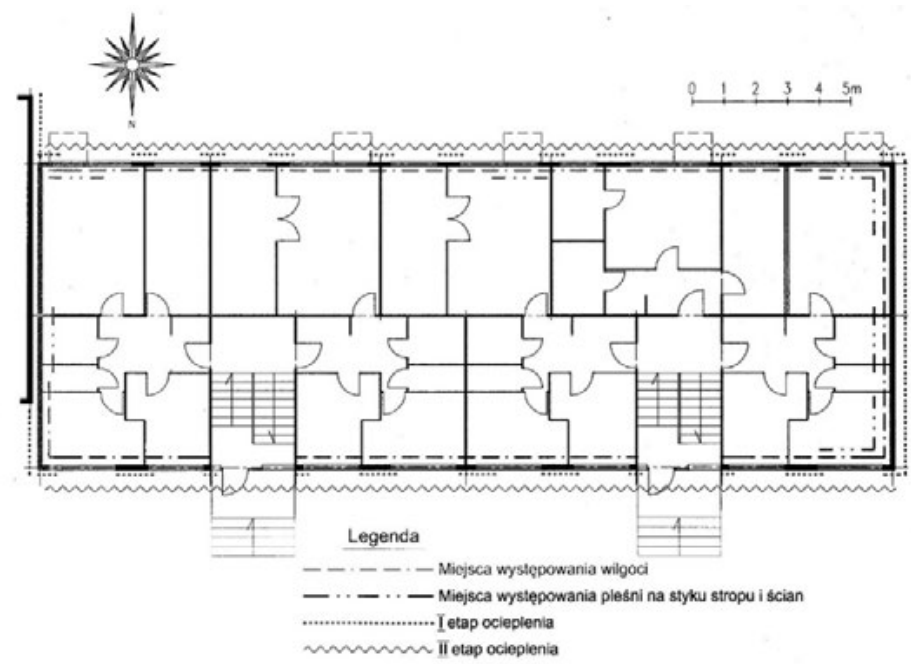

Ryc. 1. Etapy ocieplenia segmentu pięciokondygnacyjnego budynku w systemie wielkopłytowym do 2002 roku

Fig. 1 Stages of the thermal insulation project of the five-storey precast concrete building by the year 2002

W latach dziewięćdziesiątych budynki wielkopłytowe znajdujące się na osiedlu Moniuszki zostały ocieplone metodą lekką-suchą. Pierwszy etap modernizacji polegał na ociepleniu ścian szczytowych i filarków międzyokiennych, na których w ruszcie stalowym układano wełnę mineralną (o grubości $5 \mathrm{~cm}$ ) i zabezpieczano powlekaną blachą trapezową [Domińczyk 1983]. Rozwiązanie to nie zlikwidowało w pełni przemarzania ścian. $Z$ tego powodu w roku 1999 wykonano projekt drugiego etapu ocieplenia pozostałych ścian metodą BSO [Ostrowska 2003]. Zaprojektowano ocieplenie belko-ściany styropianem o grubości $6 \mathrm{~cm}$. Po sprawdzeniu obliczeń okazało się, że grubość docieplenia jest niewystarczająca i nie spełnia warunków normowych (pominięto dodatki na mostki liniowe i punktowe). W związku z powyższym w trakcie realizacji zwiększono grubość materiału izolacyjnego o $2 \mathrm{~cm}$. Ponownej wymiany ocieplenia na filarkach międzyokiennych projekt nie uwzględniał, ale zarządca zdecydował się na to ze względu na oszczędności w eksploatacji. Ściany szczytowe pozostawiono bez zmian.

Prace drugiego etapu zrealizowano w latach 2001-2002 (Ryc. 2). Ocieplenie filarków polegało na wymianie $5 \mathrm{~cm}$ wełny mineralnej na $10 \mathrm{~cm}$ styropianu, który zabezpieczono wyprawą cienkowarstwową na siatce $\mathrm{z}$ włókna szklanego. Na fasadach zachowano podział na elementy konstrukcyjne obiektu, przeniesiono go na warstwę ocieplenia poprzez boniowanie.

3 Znajdują się na nim dwa reprezentatywne systemy w Polsce, tj.: wielkopłytowy OWT-67 i wielkoblokowy WBLŻ (konstrukcyjnie realizowany do dziś). 
W styropianie wytapiano, imitując boniowanie, podział elewacji na belko-ściany i filarki, a następnie wykonywano obróbkę powierzchni styropianu. Jakość wykonania dociepleń jest dobra. Zrealizowany projekt nie uwzględniał jednak w obliczeniach punktowych i liniowych mostków termicznych. Mimo tych zabiegów mostki punktowe widoczne są na elewacji już podczas kilkunastostopniowego mrozu na tyle wyraźnie, że można policzyć kołki mocujące poszczególne płyty styropianu.

W analizowanym osiedlu na żadnym $\mathrm{z}$ dwóch etapów ocieplenia nie sprawdzono stanu technicznego wieszaków, na których do konstrukcji zamocowana jest warstwa fakturowa w ścianie trójwarstwowej. Nie połączono też przed dociepleniem warstwy fakturowej ściany ze ścianą konstrukcyjną poprzez dodatkowe kotwy rozprężne, co dałoby pewność pełnej współpracy tych warstw w ocieplanej przegrodzie.

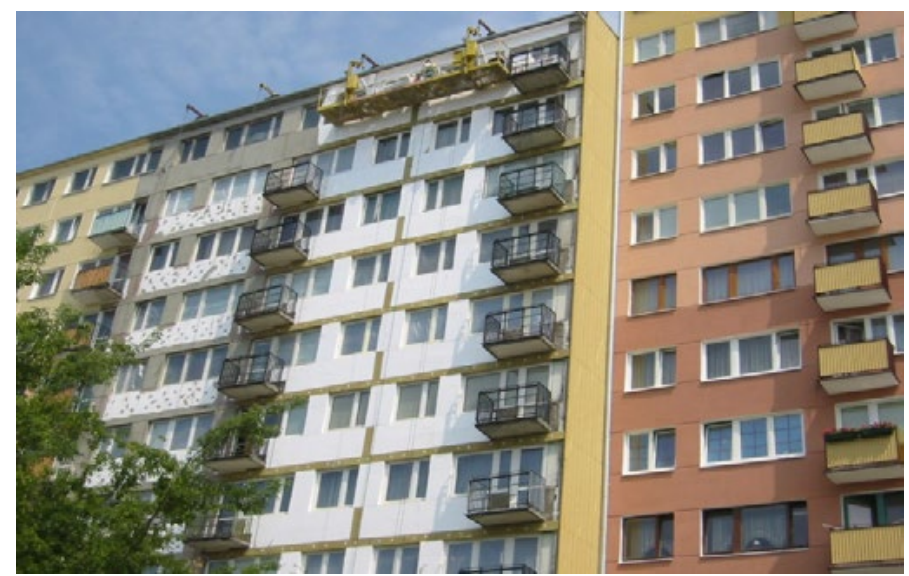

Ryc. 2. System wielkopłytowy, ocieplenie wykonano bez oceny stanu technicznego wieszaków, budynek w I. etapie ocieplono - ściany szczytowe i filarki - metoda lekka-sucha, w II. etapie ocieplono: belkościany na fasadach i wymieniono ocieplenie na filarkach międzyokiennych - metoda BSO (styropian); zachowano detal podziału elewacji na filarki międzyokienne i belko-ściany); stan w 2003 roku

Fig. 2. Building of precast concrete plates; insulation installed with no prior structural assessment of the state of walls. Stage I: insulation of end walls and piers between windows (dry cladding). Stage II: facade insulation with polystyrene boards and render finishing; the appearance of original facade (division between horizontal strips of walls-beams and vertical piers) has been maintained; photo taken in 2003

Nie zlikwidowano nadal mostków liniowych, balkony poddano tylko naprawom bieżącym przez pomalowanie płyt balkonowych od spodu i wymianę osłonowych płyt czołowych $\mathrm{z}$ azbestowych na blachę powlekaną o niskim profilu trapezu.

Zastosowane rozwiązania nadal nie są kompleksowe w zakresie termicznej modernizacji, ponieważ pominięto straty ciepła $\mathrm{z}$ budynku w kierunku pionowym, zarówno ku górze (stropodach), jak i w dół (stropy piwnic) oraz w kierunku poziomym (cokoły, termogram Ryc. 3). 

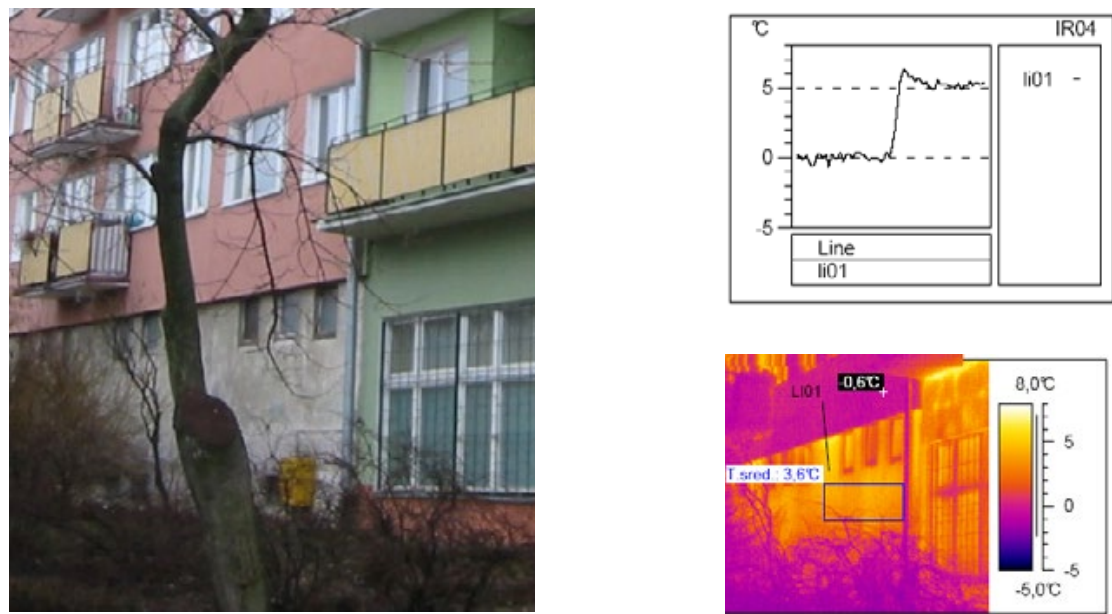

Ryc.3 Termogram, ucieczka ciepła przez cokół i ścianę piwnic Fig 3. Thermogram of basement wall
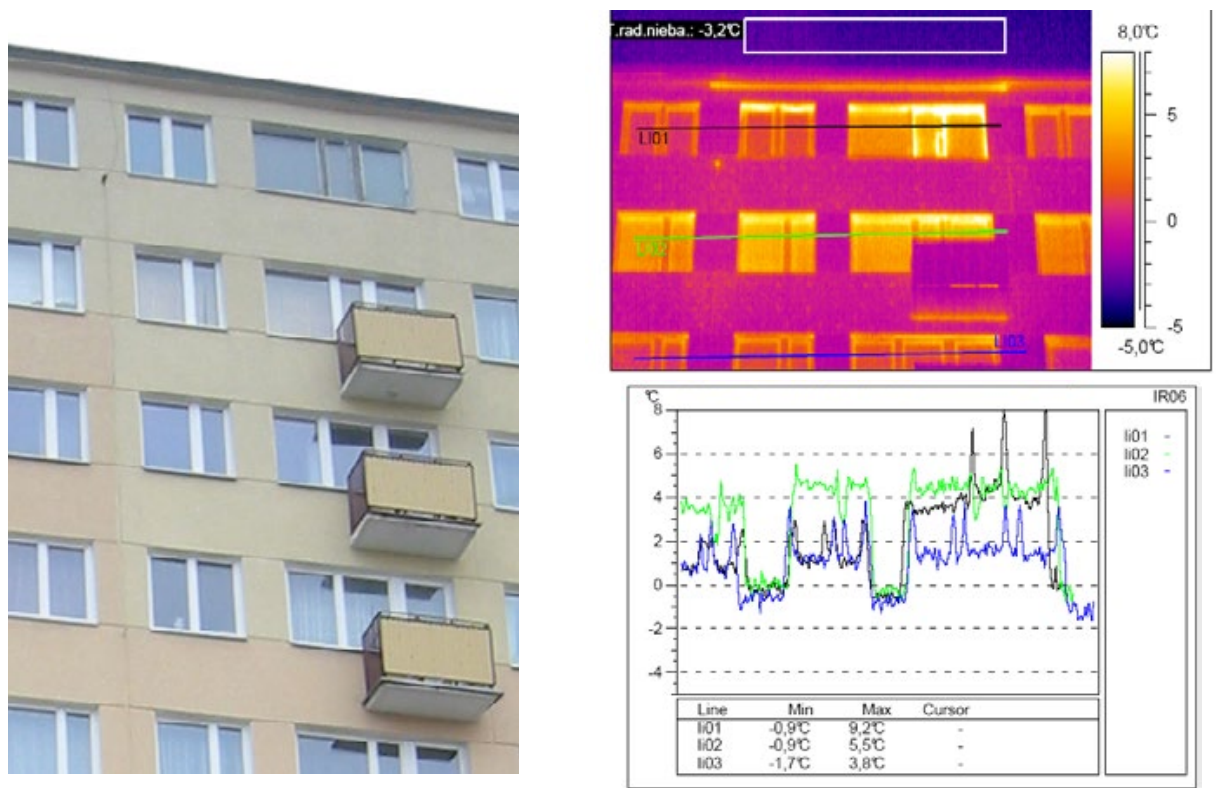

Ryc.4 Termogram, porównanie okna w mieszkaniu z oknem w suszarni pozwala oszacować średnią różnicę temperatury na $3 \mathrm{~K}$, co odpowiada różnicy w przenikalności cieplnej ok. 1,2 W/m² K. Ucieczka ciepła przez ościeża, stan marzec 2006

Fig. 4. Thermogram comparing heat distribution by windows in the flats and common utility rooms; the average temperature difference of $3 \mathrm{~K}$ corresponds to the difference of thermal conductivity of $1,2 \mathrm{~W} / \mathrm{m}^{2} \mathrm{~K}$. Photo taken in 2006 . 

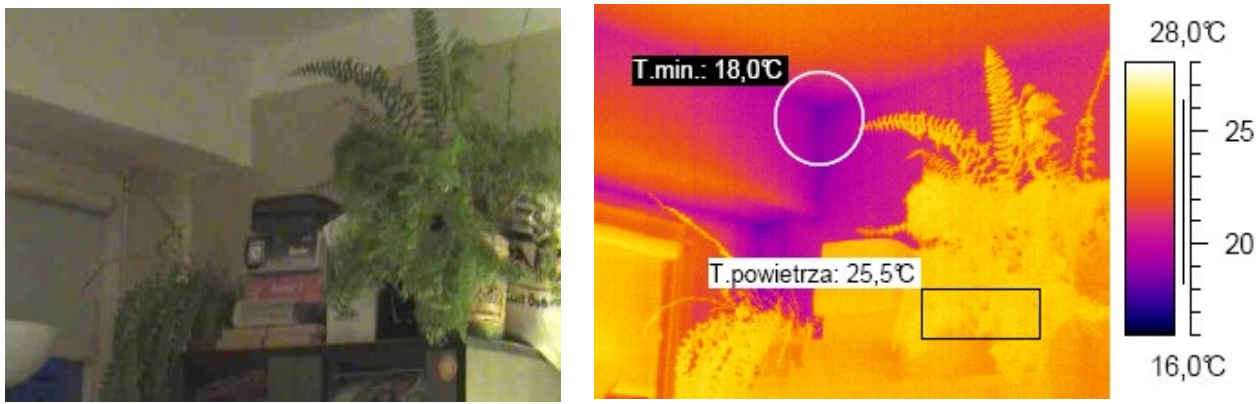

Ryc.5 Termogram, narożnik północno-zachodni ucieczka ciepła przez ścianę półszczytową i belko-ścianę Fig. 5. Thermogram, the north-west corner heat loss.

Pozostawiono mostek termiczny w ościeżach (termogram, Ryc. 4) i od strony belki nadprożowej (termogram, Ryc. 5). Nie uporządkowano pod względem termicznym stolarki okiennej (termogram, Ryc. 4). Poważną wadą ocieplenia są kołki mocujące styropian, widoczne termicznie nawet z odległości ok. $50 \mathrm{~m}$ (termogram, Ryc. 4).

W latach 2002-2003, mimo wykonania kolejnej warstwy pokrycia dachowego papy, nie docieplono stropodachów. Dopiero w roku 2005 ocieplenie wykonano na pierwotnie ułożonej wełnie gr. $5 \mathrm{~cm}$ za pomocą wdmuchiwania ekofibru o gr. $15 \mathrm{~cm}$. Podczas realizacji docieplenia ścian zamknięto możliwość przewietrzania wentylowanego stropodachu, ponieważ lokalnie zaklejono styropianem otwory wentylacyjne w ściankach kolankowych. Wytwarzane pod pokryciem z papy ciśnienie pary wodnej, wynikające z okresowo dużej różnicy temperatur, może spowodować zawilgocenie izolacji termicznej stropu ostatniej kondygnacji.

Przegląd instalacji w budynku wykazał, że aluminiowa instalacja elektryczna jest w złym stanie technicznym. W trakcie jest wymiana pionów instalacyjnych na klatkach schodowych, ale instalację $\mathrm{w}$ mieszkaniach remontują lub wymieniają mieszkańcy we własnym zakresie. Sprawdzenia wymagają również pozostałe instalacje: wentylacyjna, gazowa, c.o., c.w.u. i wodno-kanalizacyjna, gdyż są to instalacje po trzydziestoletniej eksploatacji.

Oprócz wyżej omówionych prac modernizacji termicznej w latach 1998-1999 wykonano również na osiedlu modernizację węzła cieplnego i wprowadzono podzielniki zużycia ciepła w mieszkaniach. W roku 2005 rozpoczęto wymianę sieci cieplnej realizowaną przez Lubelskie Przedsiębiorstwo Energetyki Cieplnej.

Przy dociepleniu ścian i wymianie stolarki okiennej, nie zwracano uwagi na usprawnienie wentylacji, której wydajność jest ograniczona w wyniku doszczelniania ścian i stropodachu. Brak poprawy wentylacji pomieszczeń może spowodować nasilenie się rozwoju pleśni w okresie wzrostu zawilgocenia. Dodatkowo mieszkańcy samowolnie powiększają łazienki poprzez wyburzenie trzonu bloków wentylacyjnych (Ryc. 6) lub podłączają się do kanałów sąsiadów, np. z okapami kuchennymi, co powoduje zakłócenia ciągu. 


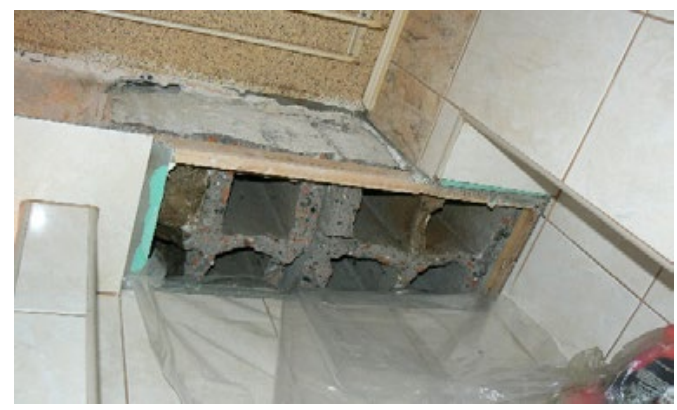

Ryc. 6 Wentylacyjne kanały zbiorcze budynek prefabrykowany - samowolnie wyburzone

Fig. 6. Common ventilation ducts - a precast ventilation block removed by the thoughtless flat owner

W celu sprawdzenia drożności przewodów wentylacyjnych i spalinowych wykonano badania diagnostyczne specjalistyczną kamerą Monitor ORCUS (Ryc. 7), która wykazała zakłócenia w drożności badanych kanałów. Niebezpieczne dla sprawnego działania wentylacji są samowolne przekucia przewodów kominowych przez lokatorów. Gruz z przekuć zalega w kanałach tworząc przeszkodę dla usuwanego z mieszkań zużytego powietrza (Ryc. 8).

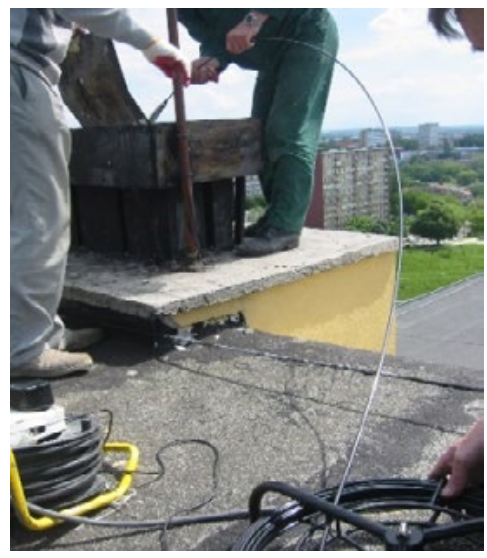

Ryc. 7. Badanie drożności wentylacji 11-kondygnacyjnego budynku prefabrykowanego

Fig. 7. Ventilation ducts inspection in a 11-storey precast concrete plate building

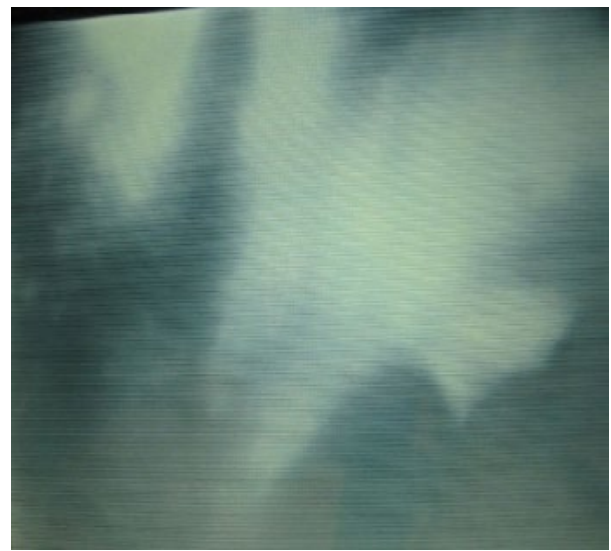

Ryc. 8. Widoczne zakłócenia drożności przewodu wentylacji na poziomie VII. kondygnacji, podgląd kamerą wziernikową Monitor ORCUS

Fig. 8. Disturbances in air flow in ventilation ducts, 7 th floor; image by Monitor ORCUS inspection camera

Wymienione zaniedbania eksploatacyjne są przyczyną pogorszenia stanu technicznego budynku, ponieważ mają wpływ na trwałość materiałów z jakich został on wykonany, a wieloletnie utrzymywanie stanu podwyższonej wilgotności w węzłach zmniejszyło trwałość zastosowanych w nich materiałów (takich jak: stal, beton i ocieplający węzły gazobeton).

Badania in situ instalacji budynku pokazały ponadto, że instalacja:

- elektryczna aluminiowa jest przestarzała i niewydajna, należy ją wymieniać na miedzianą, w 2005 roku rozpoczęto wymianę pionów klatkowych, jednak w mieszkaniach nie przewidziano żadnych działań;

- gazowa jest spawana (szczelna bez możliwości rozkręcenia) i na bieżąco konserwowana, ale znajduje się zbyt blisko instalacji wodnych, które negatywnie wpływają na trwałość rur gazowych, ulegających szybszej korozji w środowisku wilgotnym; 
- c.o. i c.w.u. z rur stalowych ocynkowanych (ryc. 9) w piwnicach są ocieplone, jednak stan złączek jest zły, zaawansowana korozja przechodzi na odcinki proste;

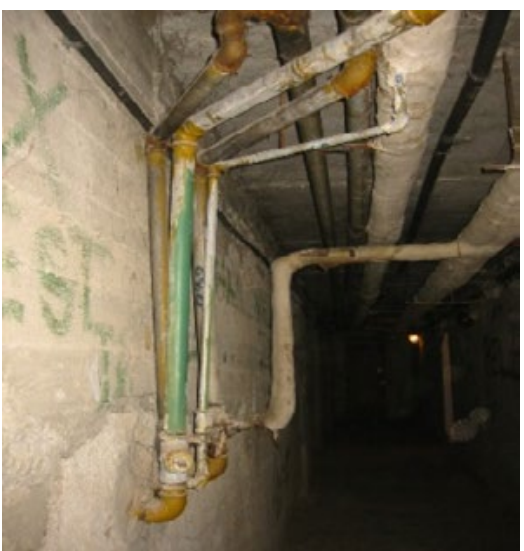

Ryc. 9. Budynek prefabrykowany piwnice, stan instalacji c.w.u. i c.o.

Fig. 9. A precast concrete plate building: condition of hot water and central heating systems

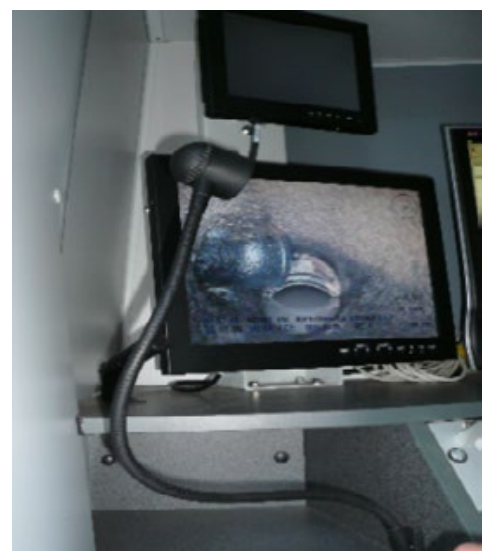

Ryc. 10. Kanalizacyjna studzienka rewizyjna, brak złogów, podgląd kamerą wziernikowa przez MPWiK

Fig. 10. Sewer inspection chamber, no deposits observed, picture taken by means of an inspection camera by a municipal water company.

- wodno-kanalizacyjna jest żeliwna, lokalnie z PCV w mieszkaniach po remontach, ogólnie w stanie dobrym (lokalnie złym), co potwierdzają bieżące przeglądy i podgląd specjalistyczną kamerą wziernikową, wykonany przez MPWiK ${ }^{4}$ W czynnym przewodzie nie zauważono złogów znacząco zmniejszających przekrój rury (Ryc. 10), choć zdarzają się miejsca, gdzie instalacja jest zamulona.

\section{EFEKTY TERMOMODERNIZACJI}

Struktura kosztów Gospodarki Zasobami Mieszkaniowymi ${ }^{5}$ w osiedlu im. Stanisława Moniuszki za rok 2002 [Skulimowski 2003] była następująca:

- c.o., c.w. $-39 \%$,

- woda i kanalizacja - $12 \%$,

- fundusz remontowy $-23 \%$.

Stwierdzono znaczny potencjał środków, które można będzie odzyskać dzięki prawidłowo planowanym i realizowanym zadaniom. Duży udział kosztów eksploatacyjnych c.o. ma swe źródło często w wadach technicznych tego typu budynków, związanych z wysoką energochłonnością i mało świadomą gospodarką ciepłej i zimnej wody (przez mieszkańców). Oprócz tego w przypadku obu systemów istotna jest również likwidacja mostków cieplnych w pasie przyziemia oraz wykonanie wtórnego obiegu wody.

Efektywność energetyczną oszacować można na podstawie kosztów zrealizowanych inwestycji na tle wynikających z nich oszczędności energetycznych.

4 Fotografia (Ryc.10) udostępniona przez zarządcę.

5 GZM, to skrót gospodarka zasobami mieszkaniowymi, w strukturę kosztów wchodzą: fundusz remontowy, wynagrodzenia, energia elektryczna, podatki i opłaty gruntowe, wywóz nieczystości, konserwacja bieżąca budynków, instalacji i urządzeń, utrzymanie zieleni osiedlowej, zimna woda i kanalizacja, energia cieplna, pozostałe koszty (bankowe, ubezpieczenia, transport, itp.), koszty zarządzania. 
Na podstawie wyliczeń zawartych w podsumowaniu bilansu finansowego roku 2002 oszacowano efektywność dotychczasowych termicznych modernizacji. Badaniami objęto wydatki na c.o. w skali całego osiedla w latach 1996-2004. Wyniki przedstawiono na Ryc.11. Rozliczenie energii cieplnej (c.o. i c.w.) na analizowanym osiedlu w zasobach mieszkalnych za rok 2002 kształtowało się na poziomie:

przychody

rozchody

dając bilans dodatni wynoszący
$2.854 .123,98 \mathrm{zl}$

$2.650 .576,01 \mathrm{zl}$

203.547,97 zł netto.

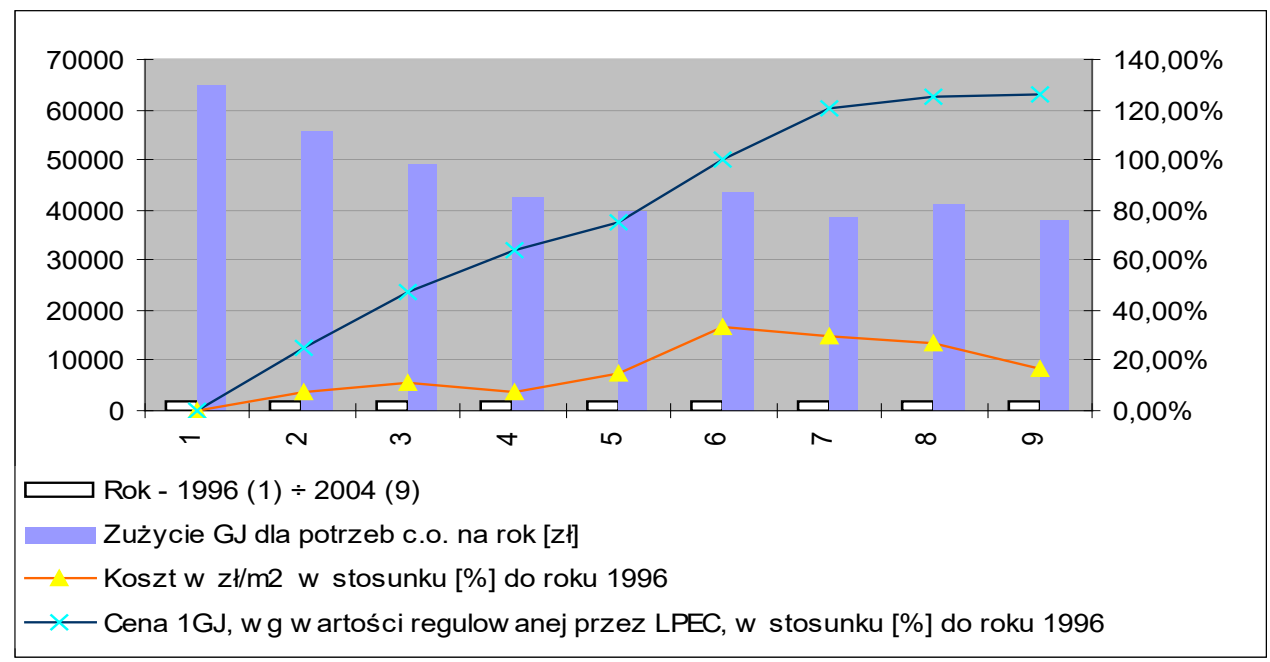

Ryc. 11. Struktura kosztów c.o. w osiedlu im. St. Moniuszki w latach 1996-2004, opracowana na podstawie danych uzyskanych u zarządcy osiedla w roku 2005

Fig. 11. Heating cost structure in Moniuszko Housing Estate, 1996-2004, based on cost records of the Estate's facility manager.

Zużycie energii cieplnej dla potrzeb c.o. budynków w osiedlu Moniuszki porównano w latach $1996 \div 2004$. Założono przy tym, że zużycie energii dla potrzeb c.o., na tle przeprowadzonych termomodernizacji, przedstawione zostanie jako zależność liniowa kosztu jednostkowego ogrzania $1 \mathrm{~m}^{2}$ powierzchni użytkowej i zmiany ceny regulowanej przez dostawcę ciepła. Jako bazowe przyjęto dane z $1996 \mathrm{r}$.

Analizując strukturę kosztów w osiedlu (Ryc. 11) potwierdzono efekty przeprowadzonych prac termomodernizacyjnych i stwierdzono, że na przestrzeni sześciu lat (1996-2002) na osiedlu Moniuszki wzrost ceny jednego gigadżula energii wyniósł $117 \%$, a koszty ogrzania $1 \mathrm{~m}^{2}$ zwiększyły się tylko o 29,61\%. A na przestrzeni kolejnych dwóch lat (2002-2004) wzrost ceny jednego gigadżula energii wyniósł $125 \%$, a koszty ogrzania $1 \mathrm{~m}^{2}$ zwiększyły się już tylko o ok. $18 \%$. Jest to jeden z lepszych wyników spośród siedmiu osiedli Spółdzielni Mieszkaniowej Czechów [Sprawozdanie... 2002].

Oszczędności te uzyskano dzięki konsekwentnej realizacji dociepleń zmierzającej do racjonalnego gospodarowania ciepłem w zasobach mieszkaniowych. Dodać należy, że efekty te uzyskano mimo braku opracowania kompleksowych działań i zasileń kredytowych, a jedynie za pomocą etapowania działań. Proces ten nadal nie został zakończony. Można zatem oczekiwać, że przy zaplanowaniu i przeprowadzeniu kompleksowej modernizacji będą one jeszcze większe. 


\section{PODSUMOWANIE}

W analizowanym systemie wielkopłytowym stwierdzono pewne możliwości poprawy stanu budynków. Należy stwierdzić, że ściany, okna i dach zabezpieczają obiekt przed warunkami atmosferycznymi w sposób właściwy, choć nadal niepełny pod względem termicznym.

Dotychczasowe działania powstrzymały przyspieszoną degradację budynków, ale wymagają one dalszych napraw i uzupełnień poszczególnych elementów.

Przeprowadzone prace modernizacyjne związane były głównie z obniżeniem kosztów eksploatacji budynków mieszkalnych. Oparto je na, wynikających z kart przeglądu stanu technicznego budynku, wybiórczych działaniach naprawczych, likwidujących niektóre problemy termiczne. Zrobiono już wiele dla poprawy estetyki i zmniejszenia energochłonności budynków oraz ochrony środowiska na obszarze osiedla.

Termiczna modernizacja ścian we wszystkich budynkach przeprowadzana była wielokrotnie, jednak nie była to kompleksowa termiczna modernizacja budynku. Nie uwzględniono problemów dotyczących ucieczki ciepła szczególnie przez mostki liniowe.

Nadal możliwe są pewne działania, które przyniosą dalsze oszczędności energetyczne, a co za tym idzie - również finansowe. Upatrywać ich należy w odnawialnych źródłach ciepła, które ostatnio coraz powszechniej są stosowane w Polsce, choć jak dotąd najczęściej w zabudowie jednorodzinnej.

Takie rozwiązania powinny być przyczynkiem do planowania programów rewitalizacji dla osiedli z prefabrykowaną zabudową mieszkalną, których jest w Polsce wiele.

This work was financially supported by Ministry of Science and Higher Education in Poland within the statutory research number S19/XX/201X.

\section{PIŚMIENNICTWO}

Domińczyk W., Luśnia K., Gawroński S., 1983. Docieplenie ścian szczytowych budynków na osiedlach „Wieniawskiego”, „Moniuszki”, ,Lipińskiego”- tom III i V - rozwiązania zamienne mocowania elewacji dla ścian bud. OWT w złym stanie technicznym, C.O.B. - P.B.P. BISTYP, Warszawa.

Ostańska A., 2009. Podstawy metodologii tworzenia programów rewitalizacji dużych osiedli mieszkaniowych wzniesionych w technologii uprzemystowionej na przykładzie osiedla im. St. Moniuszki w Lublinie, Politechnika Lubelska, Monografie Wydziału Inżynierii Budowlanej i Sanitarnej Vol.1, Wydawnictwa Uczelniane Lublin, ss.61-99.

Ostrowska H., Komor E., 2003. Docieplenie i kolorystyka elewacji istniejącego budynku mieszkalnego wielorodzinnego, w: Projekt Budowlany budynku mieszkalnego nr 9, P.P.W. EL-KOM, Lublin, s. 5.

PN-83/B-03430 Wentylacja w budynkach mieszkalnych, zamieszkania zbiorowego i użyteczności publicznej - Wymagania.

PN-EN ISO 6946:1999. Komponenty budowlane i elementy budynku. Opór cieplny i współczynnik przenikania ciepła. Załącznik NA.

Pogorzelski J.A., Kasperkiewicz K., Geryło R., 2000. Zasady dostosowania budynków wielkoptytowych do wymagań oszczędności energii i odpowiedniej izolacyjności cieplnej przegród. Praca badawcza nr 55/3457/NF-34/00, wykonana przez ITB w Zakładzie Fizyki Cieplnej zlecona przez KBN, maszynopis, Warszawa, ss. 4-6 i 46-48 oraz analizy własnej obowiązujących przepisów.

Rozporządzenie Ministra GPiB w sprawie warunków technicznych, jakim powinny odpowiadać budynki i ich usytuowanie - tekst jednolity Dz. U. nr 15/99, poz. 140.

Rozporządzenie Ministra Infrastruktury z dnia 17 marca 2009 r. w sprawie szczegółowego zakresu i formy audytu energetycznego oraz części audytu remontowego, wzorów kart audytów, a także algorytmu oceny opłacalności przedsięwzięcia termomodernizacyjnego (Dz. U. 43/2009 poz. 346)

Rozporządzenie Ministra Infrastruktury z dnia 17 marca 2009 r. w sprawie szczegółowego sposobu weryfikacji energetycznego i części audytu remontowego oraz szczegółowych warunków, jakie powinny spełniać podmioty, którym Bank Gospodarstwa Krajowego może zlecać wykonanie weryfikacji audytów Dz. U. 43/2009 poz. 347). 
Rozporządzenie Ministra Infrastruktury z dnia 6 listopada 2008r. zmieniające rozporządzenie w sprawie warunków technicznych, jakim powinny odpowiadać budynki i ich usytuowanie - niniejsze rozporządzenie dokonuje w zakresie swojej regulacji wdrożenia dyrektywy 2002/91/WE Parlamentu Europejskiego i Rady z dnia 16 grudnia 2002 r. w sprawie charakterystyki energetycznej budynków (Dz. Urz. UE L 1 z 04.01.2003 str. 65; Dz. Urz. UE Polskie wydanie specjalne Rozdział 12, tom 2, str. 168).

Skulimowski M., 2002. Sprawozdanie z działalności gospodarczej osiedla im. St. Moniuszki w Lublinie za rok 2002, Lublin 28.04. ss. 1, 4.

Sprawozdanie Zarządu Spółdzielni Mieszkaniowej Czechów z działalności w roku 2002 roku, stan na 31.12.2002r.

Ustawa o wpieraniu termomodernizacji i remontów z dnia 21 listopada 2008r. (Dz. U. Nr 223, poz. 1459)

Ustawa z dnia 18 grudnia 1998 r. o wspieraniu przedsięwzięć termomodernizacyjnych (Dz. U. Nr 162, poz. 1121, z późn. zm).

\title{
THE EFFECTS OF CURRENT PROJECTS ON IMPROVING ENERGY PERFORMANCE OF RESIDENTIAL BUILDINGS VS PERSPECTIVES FOR NEW URBAN REGENERATION PROJECTS
}

\begin{abstract}
Managers of large housing estates whose stock consist mainly of precast concrete plate buildings of 1970ies, due to their sheer size and technical condition far from being perfect, are especially concerned with searching for solutions that would reduce energy consumption. The paper describes the energy saving policies in Poland and results of pilot studies of Building Research Institute (ITB) aimed at defining optimal set of actions aimed at improving energy performance of precast concrete plate housing. The paper investigates into the effects of projects taken in a particular, though typical, housing estate in Lublin in order to give grounds for future actions in the field of energy saving measures.
\end{abstract}

Key words: improving building energy performance, energy saving, urban regeneration. 